\title{
Bioelectricity Generation and Production of Ornamental Plants in Vertical Partially Saturated Constructed Wetlands
}

\author{
Humberto Raymundo González-Moreno ${ }^{1,2}$, José Luis Marín-Muníz ${ }^{2}$ (), Eddy Sánchez-DelaCruz ${ }^{3}$,

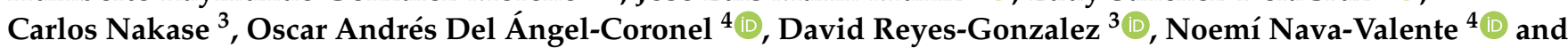 \\ Luis Carlos Sandoval-Herazo $3,5, *$ (1)
}

check for

updates

Citation: González-Moreno, H.R.; Marín-Muníz, J.L.; Sánchez-DelaCruz, E.; Nakase, C.; Del Ángel-Coronel, O.A.; Reyes-Gonzalez, D.;

Nava-Valente, N.; Sandoval-Herazo, L.C. Bioelectricity Generation and Production of Ornamental Plants in Vertical Partially Saturated Constructed Wetlands. Water 2021, 13, 143. https://doi.org/10.3390/ w13020143

Received: 19 November 2020 Accepted: 5 January 2021 Published: 9 January 2021

Publisher's Note: MDPI stays neutral with regard to jurisdictional clai$\mathrm{ms}$ in published maps and institutional affiliations.

Copyright: (C) 2021 by the authors. Licensee MDPI, Basel, Switzerland. This article is an open access article distributed under the terms and conditions of the Creative Commons Attribution (CC BY) license (https:// creativecommons.org/licenses/by/ $4.0 /)$.
1 Departamento de Ingeniería Civil, Tecnológico Nacional de México/Instituto Tecnológico Superior de Misantla, Km 1.8 Carretera a loma del Cojolite, Misantla, Veracruz, C.P. 93821, Mexico; hrgonzalezm@misantla.tecnm.mx

2 Sustainable Regional Development Academy, El Colegio de Veracruz, Xalapa, Veracruz 93164, Mexico; soydrew@hotmail.com

3 Division of Postgraduate Studies and Research, Tecnológico Nacional de México/Instituto Tecnológico Superior de Misantla, Km 1.8 Carretera a loma del Cojolite, Misantla, Veracruz, C.P. 93821, Mexico; esanchezd@misantla.tecnm.mx (E.S.-D.-C.); cynakaser@misantla.tecnm.mx (C.N.); dreyesg@misantla.tecnm.mx (D.R.-G.)

4 Tecnológico Nacional de México/Instituto Tecnológico Superior de Huatusco. Av. 25 Poniente No. 100, Col. Reserva Territorial, Huatusco, Veracruz, C.P. 94100, Mexico; oscardelangel.coronel@hotmail.com (O.A.D.Á.-C.); noemi_nava@itshuatusco.edu.mx (N.N.-V.)

5 Master of Engineering in Tecnológico Nacional de México/Instituto Tecnológico Superior de San Andrés Tuxtla, San Andrés Tuxtla, Veracruz, C.P. 95804, Mexico

* Correspondence: lcsandovalh@gmail.com

\begin{abstract}
Energy production in constructed wetlands is a little-known field, as is the operation of vertical partially saturated constructed wetlands (VPS-CWs) that promote both aerobic and anaerobic microbial interactions. By doing so, bacterial degradation is increased, becoming the main mechanism of pollutant removal in constructed wetlands (CWs). For the first time, the generation of bioelectricity, together with the production of ornamental plants in vertical partially saturated constructed wetlands during the treatment of domestic wastewater, was evaluated. Six VPS-CW systems functioned as bioelectricity generators, where the systems were filled with red volcanic gravel and activated carbon as anode and cathode. Three systems were planted with Zantedeschia aethiopica and three with Canna hybrids plants. The development was measured through mother plants and shoots produced every 60 days. The input and output of each VPS-CW was monitored using control parameters such as $\mathrm{BOD}_{5}$, phosphates $\left(\mathrm{P}-\mathrm{PO}_{4}\right)$, and total Kjeldahl nitrogen (TKN). Bioelectricity, power, voltage, and current measurements were performed every 15 days for a period of 7 months. It was found that the VPS-CWs used as biobatteries in combination with the use of domestic wastewater as a substrate improved the development of the two evaluated plant species and stimulated growth and germination of new shoots. No significant differences were found between the different treatments $(p \leq 0.05)$. Likewise, an average efficient removal of $\mathrm{BOD}_{5}(98 \%)$ for both systems without statistical differences was observed ( $p \leq 0.05)$, but for TKN and $\mathrm{P}_{-} \mathrm{PO}_{4}$, significant differences $(p \leq 0.05)$ were

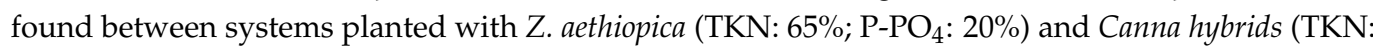
$69 \%$; $\mathrm{P}_{-} \mathrm{PO}_{4}: 27 \%$ ). This method of water treatment and bioelectricity production with Canna hybrids was an efficient system that generated a great electric current $\left(140 \mathrm{~mA} / \mathrm{m}^{2}\right)$, voltage $(750 \mathrm{mV})$, and electric power $\left(15 \mathrm{~mW} / \mathrm{m}^{2}\right)$, compared with those observed in systems with Z. aethiopica $\left(60 \mathrm{~mA} / \mathrm{m}^{2}\right.$, $\left.500 \mathrm{mV}, 9 \mathrm{~mA} / \mathrm{m}^{2}\right)$.
\end{abstract}

Keywords: bioelectricity; constructed wetlands; microbial combustion cells; ornamental plants 


\section{Introduction}

Vertical partially saturated constructed wetlands (VPS-CWs) are an emerging technology for domestic and industrial wastewater treatment, the operation of which is not clearly known [1]. All these VPS-CWs involve four main components: water, substrate, plant, and microbial interaction by the action of aerobic and anaerobic microorganisms that degrade pollutants through biochemical processes $[2,3]$ and are fundamental to the bioremediation that takes place in these bioprocesses. Aerobic and anaerobic conditions that can allow contaminants to be removed are incorporated into VPS-CWs in a single treatment system, thus reducing the number of solids in the water and, in turn, making the process efficient $[4,5]$. In the last decade, constructed wetlands (CWs) have become popular for their low cost of implementation, operation, and easy maintenance by moderately qualified personnel $[6,7]$. Likewise, the performance of partially saturated VF-CWs has been studied and validated during the removal of organic matter in terms of COD (chemical oxygen demand), reduction of ammonium $\left(\mathrm{NH}_{4}-\mathrm{N}\right)$, total phosphorus, and dissolved oxygen (DO) performance [8]. Being an integral system, it has the advantage of low water requirements and reduced odors $[9,10]$. Saeed et al. [11], studied the removal of organic matter and nutrients in two sequential wetlands, specifically vertical flow (VF) and horizontal flow (HF) wetlands. In that study, they found that partially saturated and shallow hybrid water depth wetland systems achieved $90 \%$ elimination of organic matter, including more than $97 \%$ of nitrogen and $100 \%$ of phosphorus. It should be noted that despite being efficient in disposal, a system that can simultaneously generate electricity and produce ornamental plants was not incorporated. Recent studies have aimed at evaluating the performance of CWs such as microbial fuel cell (MFCs) in producing bioelectricity through biochemical reactions that occur in these systems [12-15]. The operation of these systems evokes a cell, where the zone with absence of oxygen (anaerobia) acts as an anode (zones far from roots of CW plants) and zones with presence of oxygen (aerobic) as a cathode (regions close to the root zone of $\mathrm{CW}$ plants). During the decomposition process of organic matter, the action of microorganisms acts as electron receptors, while during the oxidation process, the protons of the anode are released and travel through artificial circuits to the cathode, thus completing the energy process through the reactions of oxide reduction (redox potential) and the oxygen available in the system $[16,17]$. The bioenergy generated by MFCs is promoted in oxide-reduction processes (the higher the redox potential, the greater the production of bioelectricity). As demonstrated by Doherty et al. (2015) [2], incorporating a microbial cell can generate the removal of organic matter of up to $70 \%, 75 \%$ ammonium removal, and $0.268 \mathrm{~W} / \mathrm{m}^{3}$. Aguirre-Sierra et al. [18] studied a wetland built with a biofilter with aerobic electroconductors, observing the presence of Geobacter and Thiobacillus that could contribute to the removal of organic matter in the form of COD, phosphorus (P), and nitrogen $(\mathrm{N})$. Incorporating the same system with electrodes could improve removal and generate bioelectricity. This occurs when the microorganisms degrade the organic matter present in the media used [19]. The CW system that works as an MFC in the presence of vegetation increases the dissolved oxygen present in the substrates due to the release of this radical area $[14,20,21]$. Research aimed at the use of CW-MFCs is recent, with limitations such as the cost of materials used to favor the generation of bioenergy and make the systems more efficient in terms of energy production. Elements of these novel systems that promote energy production include the anode and the cathode that treat contaminated water, which generates bioelectricity. For this reason, activated carbon and graphite [22], titanium and activated carbon [15], graphite and titanium [23], and copper and carbon fiber [13] are commonly used as electrodes. These materials promote the conduction of energy due to their properties and their generation in the CW-MFC through the degradation of pollutants and organic matter. However, this biotechnology is far from the reach of communities with limited resources. Rural communities in developing countries suffer from the need for wastewater treatment and energy supply [24] due to their high cost [25] or implementation in large-scale systems [26]. Operating mechanisms also require hybrid aerobic and anaerobic operating conditions with the aim of improving the processes of 
elimination of pollutants [27] and the production of bioelectricity [28]. The generation of bioelectricity and the production of ornamental plants were thus evaluated in VPS-CWs during the treatment of domestic wastewater.

This VPS-CW system represents an innovation for domestic wastewater treatment, simultaneous electric power production, and ornamental plant generation. Considering that Canna hybrids are easily adapted to wetlands, as reported by some authors [29], and their typical growth is higher $(2.5 \mathrm{~m})$ than that of Zantedeshia aethiopica $(1 \mathrm{~m})$ [30], which could favor more radial oxygen release and more aerobic conditions [31], we developed the following two hypotheses: (1) Zantedeshia aethiopica adapts to constructed wetland conditions; however, its growth is lower than that of Canna hybrids, (2) pollutant removal and bioelectricity production is higher in systems with Canna hybrids compared with systems planted with Zantedeshia aethiopica.

\section{Methodology}

\subsection{Description of Vertical Partially Saturated Constructed Wetlands}

This study was carried out in Misantla, Veracruz, Mexico, at an average annual temperature of $23{ }^{\circ} \mathrm{C}$, with an average annual rainfall of $1862 \mathrm{~mm}$, considered as a tropical climate [1]. The VPS-CWs were under a $50 \%$ shade mesh $3 \mathrm{~m}$ from the experimental units. The water used came from an undiluted municipal wastewater tank, stored in a $1500 \mathrm{~L}$ container that functions as a settler. The water supply to the VPS-CWs was $160 \mathrm{~mL}$ every $2 \mathrm{~h}$, with an automated $12 \mathrm{~W}$ pump. Six cylindrical experimental units as shown in Figure 1 were used as VPS-CWs. Activated carbon sheets $20 \mathrm{~cm}$ in diameter by $3 \mathrm{~cm}$ in height, one in the free flow zone and the other in the saturation zone (Figure 1), were used as anode and cathode. An insulated copper cable was used, due to its low cost in the market, to connect an open circuit for a period of 30 days and then a closed circuit. Each system had a resistance of $1000 \Omega$ (Figure 1). Likewise, each CW experimental unit was filled with red volcanic gravel (1-3.5 $\mathrm{mm}$ ) with a 53\% porosity. Regarding the vegetation, Zantedeschia aethiopica and Canna hybrids plants were used, the exotic flowers of which were collected in their natural state with an average height of $17 \mathrm{~cm}$. Three VPS-CWs were accordingly built with Z. aethiopica and three more with Canna hybrids. Measurements started when the system was well established, on 15 January 2019.

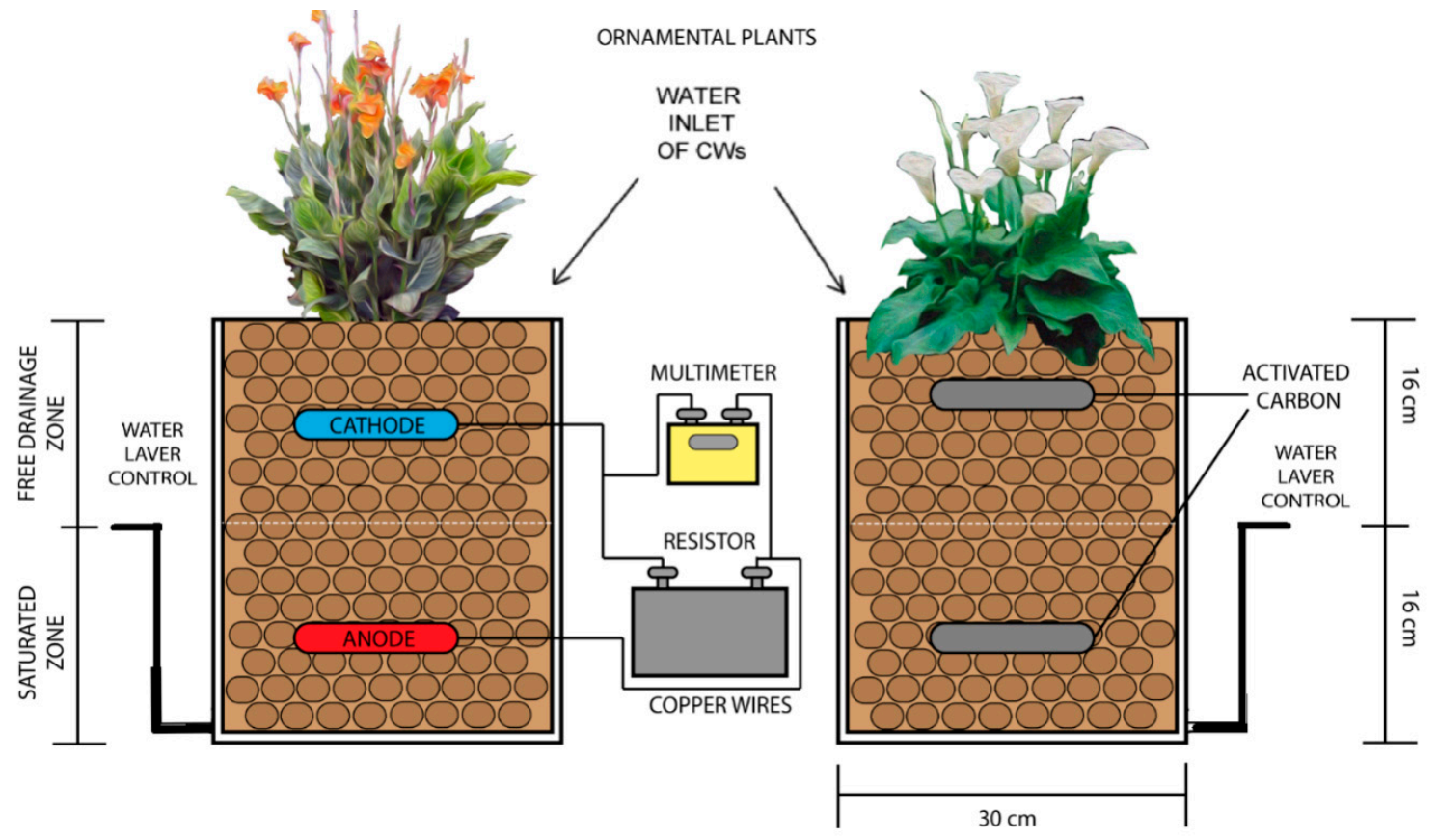

(a)

(b)

Figure 1. Wastewater treatment system using Canna hybrids (a) and Zantedeschia aethiopica (b) for bioelectricity production. 


\subsection{Production of Ornamental Plants in VPS-CWs}

To determine the production of ornamental plants in VPS-CWs, the production of shoots and the height of mother plants were monitored every 60 days during the study period.

\subsection{VPS-CW System Monitoring}

In a sample obtained from the bottom of each system, the following physical parameters were monitored as follows: dissolved oxygen, water temperature, electrical conductivity, and $\mathrm{pH}$ by means of a Milwaukee MW802 multiparameter probe meter for $\mathrm{pH} / \mathrm{EC} / \mathrm{TDS} / \mathrm{DO}$.

The following values were measured at the entrance and exit of each VPS-CW: iochemical oxygen demand (BOD 5 , by NMX-AA-028-SCF-2001), phosphates $\left({\mathrm{P}-\mathrm{PO}_{4}}_{4}\right.$, amino acid method), total Kjeldahl nitrogen, water temperature, dissolved oxygen, and $\mathrm{pH}$ (Milwaukee MW802). It should be noted that each parameter was measured in duplicate and monitored from 11 to $12 \mathrm{~h}$ every 15 days.

Generated voltage was monitored in three time ranges from 9 to 10,13 to 14 , and 18 to 19 , using an RMS Autoranging professional multimeter with a USB interface (Steren). These values were recorded every hour. The generated current was calculated using Ohm's law and the power by means of the relation:

$$
\mathrm{I}=\left(\frac{\mathrm{V}}{\mathrm{R}}\right)
$$

where $\mathrm{P}=$ power measured in watts; $\mathrm{I}=$ current measured in amps; and $\mathrm{V}=$ voltage measured in volts.

\subsection{Statistical Analysis}

A completely randomized design was used to evaluate all physicochemical and electrical parameters. The experimental unit was an individual VPS-CW with or without a plant treatment (Zantedeschia aethiopica or Canna hybrids or only substrate as control), and there were three replicates for each unit. Then, the variables were evaluated with an analysis of variance, and significant differences among means were determined using the Tukey test $(p \leq 0.05)$. Prior to analysis, normality tests were performed on the data to ensure that they fit a normal distribution curve. In this regard, all the variables present typical characteristics of a normal distribution. The standard deviation was also determined to evaluate nondestructive parameters of each ornamental plant (only one type of plant was transplanted into each VPS-CW). All data analysis was done with Minitab ${ }^{\circledR} 16$ Statistical Software. The graphs were made with SigmaPlot v.10.

\section{Results and Discussion}

\subsection{Production of Ornamental Plants in VPS-CWs}

Figure 2 shows the development of ornamental mother plants during the study period. Both species managed to adapt adequately to partially saturated conditions. Apparently, this method of feeding and operation favored growth and encouraged flower generation. In this study, 28 Canna hybrids and six Zantedeschia aethiopica flowers were produced. This could be because the environmental conditions were adequate for their development. On average, the environmental temperature was $23^{\circ} \mathrm{C}$, which is in the range of 15 to $25^{\circ} \mathrm{C}$, the ideal temperature for the development of tropical ornamental plants. Likewise, the $\mathrm{pH}$ was within the adequate range between 7 and 8 [32] for the optimal values found in this study (Figures 3 and 4 and Table 1). On the other hand, growth reports are higher than those reported by other authors, although in fully saturated conditions [33], the conditions of partially saturated and activated carbon as anode and cathode stimulate the growth of plants up to $15 \%$ more than in conditions of total saturation, as reported in studies for the same periods of time. 


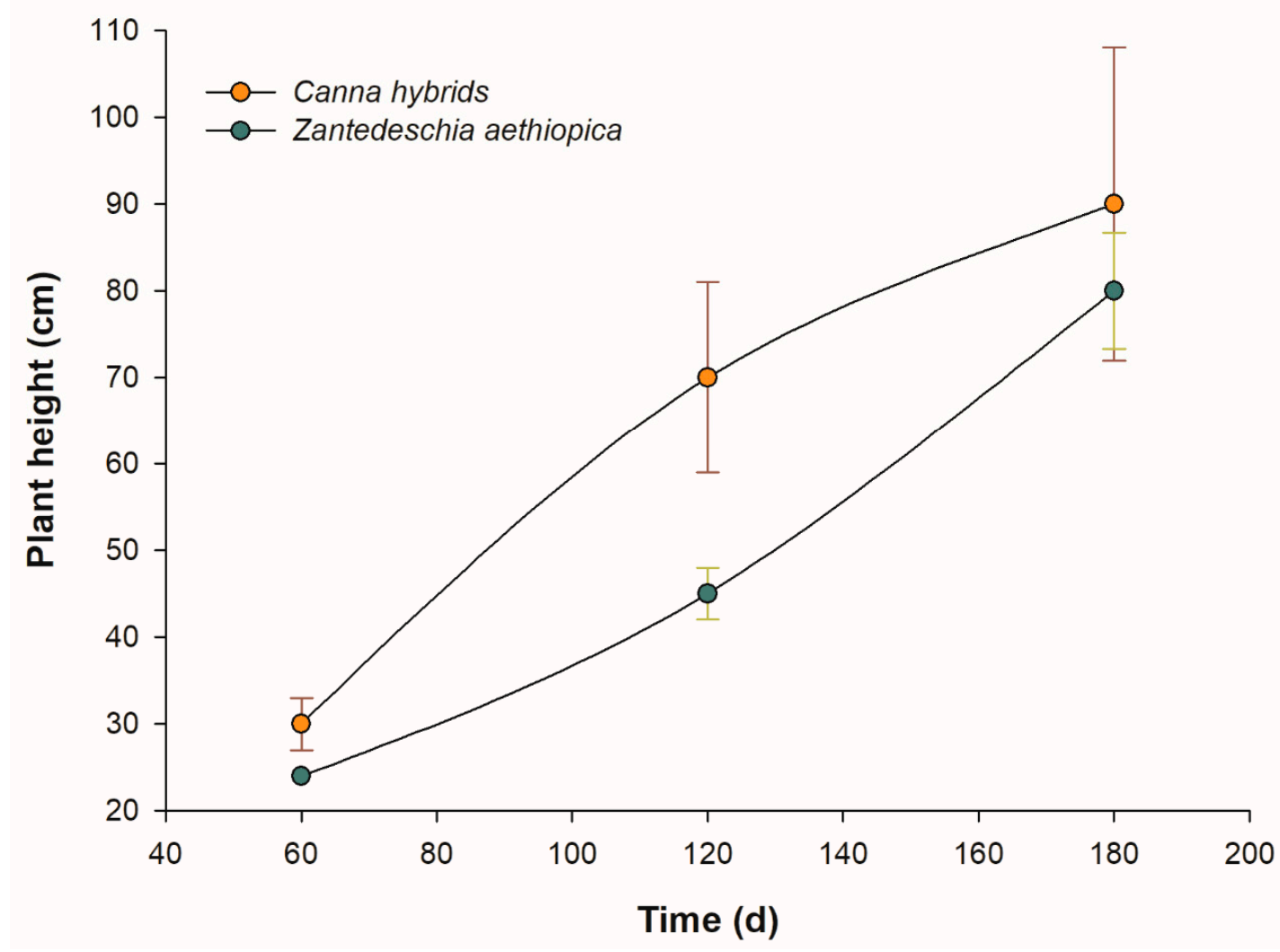

Figure 2. Growth of mother plants.

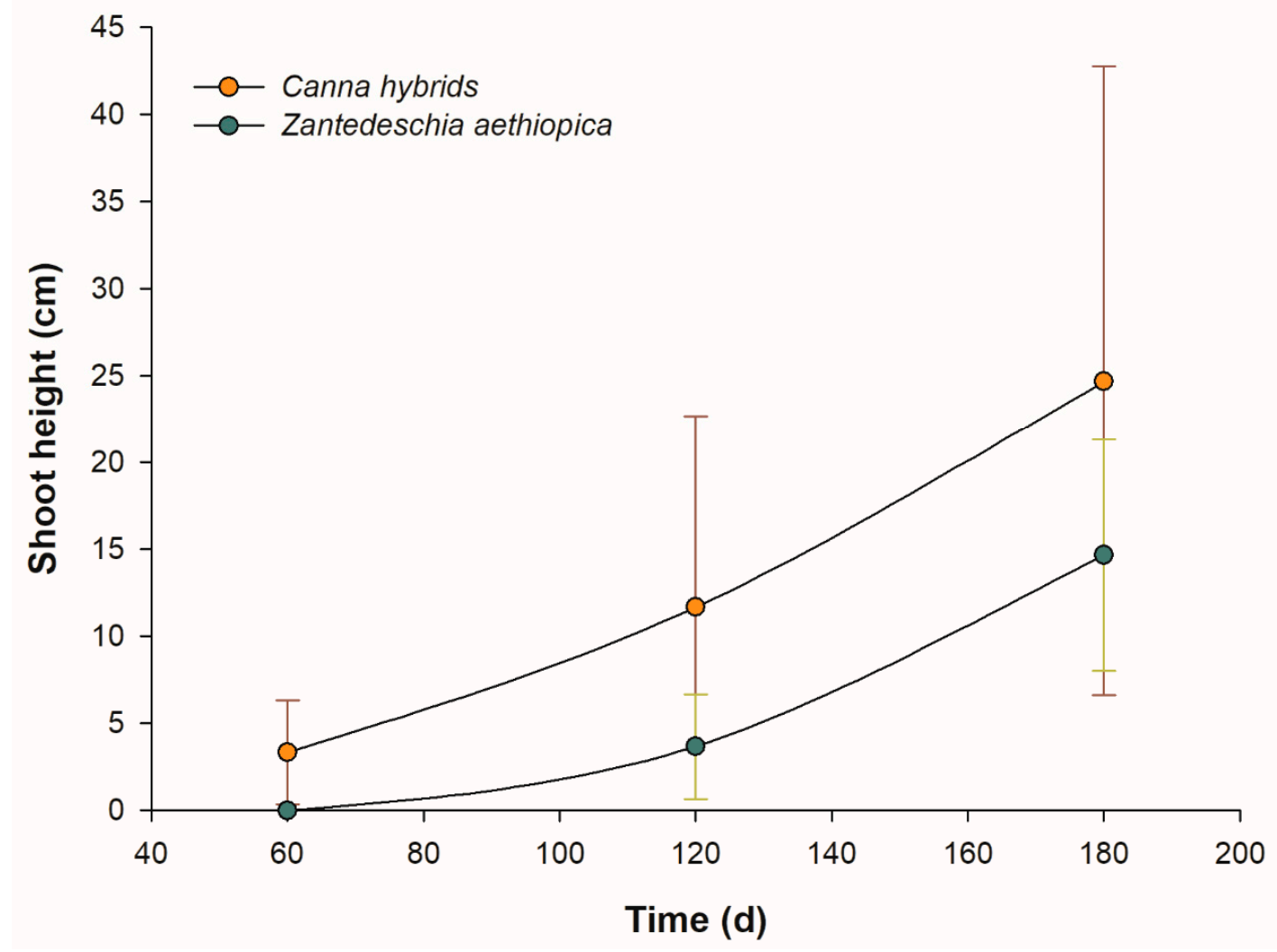

Figure 3. Growth of shoots. 


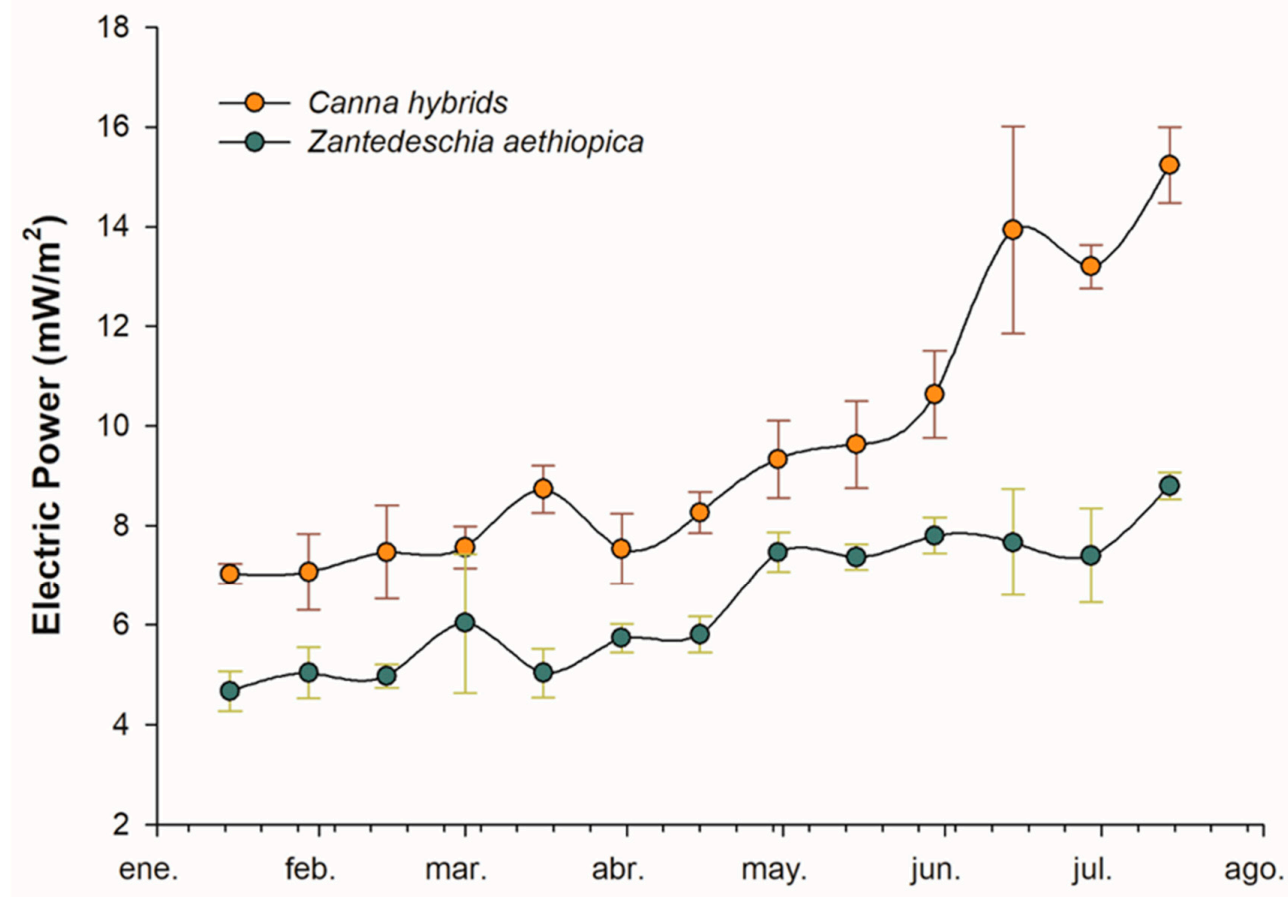

Figure 4. Comparison of maximum power $\left(\mathrm{mW} / \mathrm{m}^{2}\right)$ generated in VPS-CW systems using Canna hybrids and Z. aethiopica during 8 months of retention.

Table 1. Physicochemical parameters of input and output in VPS-CW systems with Z. aethiopica and Canna hybrids.

\begin{tabular}{|c|c|c|}
\hline Parameter & Zantedeschia aethiopica & Canna hybrids \\
\hline \multicolumn{3}{|c|}{$\mathrm{pH}$} \\
\hline Influent & \multicolumn{2}{|c|}{$7.8 \pm 0.4$} \\
\hline Effluent & $7.5 \pm 0.2$ & $7.5 \pm 0.2$ \\
\hline \multicolumn{3}{|c|}{ DO (mg/L) } \\
\hline Influent & \multicolumn{2}{|c|}{$1.4 \pm 0.3$} \\
\hline Effluent & $7.1 \pm 0.3$ & $8.7 \pm 0.4$ \\
\hline \multicolumn{3}{|c|}{ Water temperature $\left({ }^{\circ} \mathrm{C}\right)$} \\
\hline Influent & \multicolumn{2}{|c|}{$7.8 \pm 0.4$} \\
\hline Effluent & $7.5 \pm 0.2$ & $7.5 \pm 0.2$ \\
\hline \multicolumn{3}{|c|}{ BOD (mg/L) } \\
\hline Influent & \multicolumn{2}{|c|}{$286 \pm 28.4$} \\
\hline Effluent & $8.6 \pm 7.3$ & $5.4 \pm 3.1$ \\
\hline $\begin{array}{c}\text { Removal } \\
(\%)\end{array}$ & $96.9 \pm 2.5$ & $98.1 \pm 0.9$ \\
\hline \multicolumn{3}{|c|}{ TKN (mg/L) } \\
\hline Influent & \multicolumn{2}{|c|}{$87.5 \pm 16.8$} \\
\hline Effluent & $32.8 \pm 17.0$ & $26.7 \pm 11.3$ \\
\hline $\begin{array}{c}\text { Removal } \\
(\%)\end{array}$ & $64.9 \pm 12.7$ & $69.49 \pm 12.9$ \\
\hline \multicolumn{3}{|c|}{$\mathrm{P}^{-\mathrm{PO}_{4}}(\mathrm{mg} / \mathrm{L})$} \\
\hline Influent & \multicolumn{2}{|c|}{$7.9 \pm 2.7$} \\
\hline Effluent & $6.3 \pm 1.2$ & $5.8 \pm 0.3$ \\
\hline $\begin{array}{c}\text { Removal } \\
(\%)\end{array}$ & $20.2 \pm 15.2$ & $26.6 \pm 3.8$ \\
\hline
\end{tabular}


Regarding the production of shoots, Figure 3 shows the production of six Canna hybrids shoots that grew and became new plants during the study period. Similarly, Z. aethiopica produced four shoots, which developed mostly 120 days after planting. These results show an improvement on those reported by Nakase et al. [1] under similar conditions. This could be due to, unlike in the previous study, the substrates having the presence of activated carbon as anode and as cathode. This may favor the development and production of new seedlings in the systems, since activated carbon has been shown to favor the emergence of new shoots. This was observed in other studies of Citrus limon plants, such as that reported by Vasconez et al. [34], and may be related to the improved development of shoots in this study. On balance, new studies are required to demonstrate the effect of activated carbon as a stimulating medium for the development of ornamental plants in VPS-CWs with mechanisms that generate higher biomass and flower production.

\subsection{Contaminant Removal}

Table 1 shows effluent and system influent data during the study. It was found that the $\mathrm{pH}$ and temperature of the water were in adequate ranges for plant development in tropical climates [35]. Regarding the DO, we found that two mechanisms could be combined, the free drainage zone and the root pressure in the free flow zone, which could increase the presence of dissolved oxygen in the system after treatment (Table 1). Oxygen release studies in constructed humidity systems demonstrate that the presence of vegetation favors the increase in dissolved oxygen in these systems, but not in ranges greater than 0.5 to $4.6 \mathrm{mg} / \mathrm{L}[31,36]$. In this study the data showed twice the normal values reported in studies on CWs.

Biochemical oxygen demand (BOD) is an indicator of contamination or presence of organic matter in water. This helps to monitor the degradation of organic matter present in wastewater, which in turn reflects the amount of oxygen used by microorganisms (mainly aerobic bacteria), plankton, and fungi [37,38]. Table 1 depicts the elimination of BOD after treatment; the VPS-CWs managed to eliminate above $95 \%$ in both treatments, and no significant differences $(p \leq 0.05)$ were found between the systems planted with Canna hybrids and Zantedeschia aethiopica. These BOD results are superior to those reported by other studies, with $50 \%$ greater removal than in vertical flow constructed wetlands $[39,40]$ and up to $55 \%$ greater removal than in horizontal subsurface flow constructed wetlands [41,42] with BOD concentrations up to $50 \%$ lower than those presented in this study at the entry of the systems. This could be due to the conditions of the systems (Figure 1), in which the free flow zone and the saturation zone could allow a greater development of microbial communities, both aerobic and anaerobic, which are the main organic matter degraders in CWs. This proves VPS-CWs to be a suitable alternative for the removal of organic matter in wastewater when they are used as systems that generate bioelectricity, as is the case in this study. For total Kjeldahl nitrogen (Table 1$)$, significant differences $(p \leq 0.05)$ were found between systems planted with Z. aethiopica and Canna hybrids; the removal of contaminants in systems planted with Canna hybrids was 5\% higher. This may be because this plant produced a greater number of shoots, and there was a greater nitrogen requirement for its development; it is well known that nitrogen is essential for plant development [43,44]. Likewise, phosphate (Table 1) presented significant differences $(p \leq 0.05)$, showing a behavior like that of total nitrogen (Table 1 ). However, the elimination was extremely low in the system with Z. aethiopica (Table 1), being $6 \%$ higher in systems with the presence of Canna hybrids. This behavior could be due to the greater presence of vegetation and the development of young plants in the systems (Figure 3), taking into consideration that plants require the absorption of this nutrient for their development and production of flowers and fruits $[45,46]$.

\subsection{Bioelectricity Production in VPS-CWs}

The water treatment system VPS-CW was monitored for approximately 8 months, determining the system voltage over a constant period. It should be noted that the first 
60 days corresponded to microbiota adaptation (aerobic and anaerobic) and the creation of a biofilm around electrons within the same system. This system was used for domestic wastewater treatment with an initial BOD of $286 \mathrm{mg} / \mathrm{L}$, observing an organic matter removal efficiency of $96.1 \%$ in the system with Z. aethiopica and $98.1 \%$ with Canna hybrids (Table 1). It is probable that as the residual water degraded (BOD removal), the availability of electrons in the medium increased, and the power also increased exponentially with $9.7 \mathrm{~mW} / \mathrm{m}^{2}$ in the system with Canna hybrids and $6.4 \mathrm{~mW} / \mathrm{m}^{2}$ with Z. aethiopica during the experimentation period for both systems. However, a higher potency was observed when the Canna hybrids plant was used, this being the one that generated a greater removal of BOD (98.1\%) [47-50].

Figure 5 illustrates the change in peak voltage between VPS-CW systems with Canna hybrids and Z. aethiopica. In the first weeks of treatment the maximum voltage was approximately $225 \mathrm{mV}$ for the Canna hybrids system, while the Z. aethiopica system generated approximately $350 \mathrm{mV}$, higher compared to the other VPS-CW system. Likewise, it was noticed that in the first month of monitoring the change in voltage remained constant, probably because the microbiota of the medium, both aerobic and anaerobic, adapted to the substrates and the conditions of the medium. After the first month, an exponential increase in voltage $(\mathrm{mV})$ was observed reaching a maximum peak of approximately $750 \mathrm{mV}$ in the system with Canna hybrids, while the one with Z. aethiopica showed an exponential change in voltage until the second week of May with a maximum of $450 \mathrm{mV}$. It should be noted that this voltage remained until the first week of August. The difference between both VPS-CW systems was significant $(p \leq 0.05)$, with the highest voltage observed for Canna hybrids. This increase in voltage could be attributed to the availability of organic matter as the substrate was consumed. Thus, the metabolic pathway of wastewater decomposition generated more electrons in the medium that could be transferred to the anode, leading to higher voltage generation $[50,51]$.

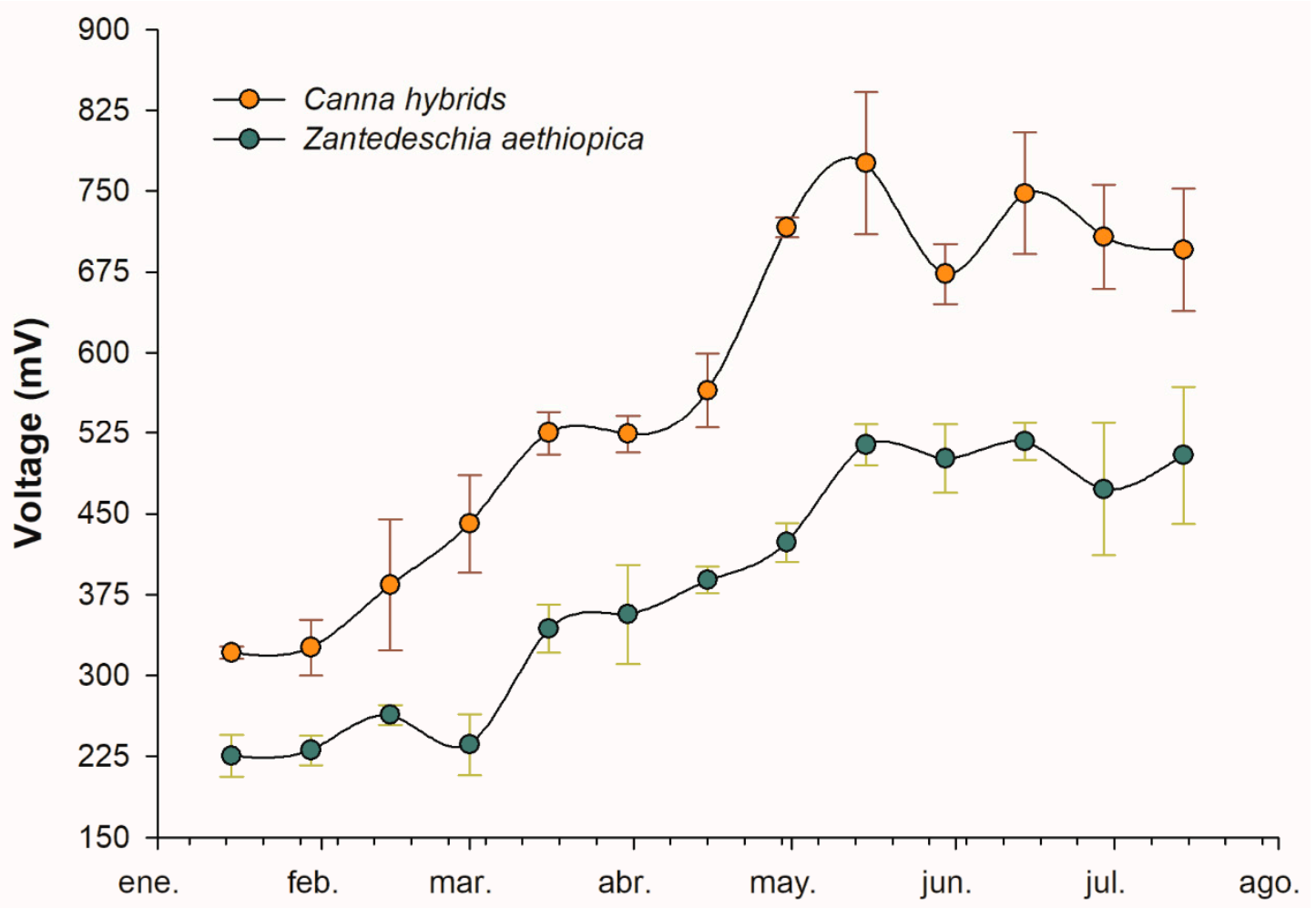

Figure 5. Comparison of the voltage $(\mathrm{mV})$ generated in VPS-CW systems using Canna hybrids and Z. aethiopica during 8 months of retention. 
Current density was calculated in systems with Canna hybrids and Z. aethiopica during the time the wetlands were in operation. As illustrated in Figure 6, the VPS-CWs with Canna hybrids obtained an initial current density of approximately $65 \mathrm{~mA} / \mathrm{m}^{2}$, while the VPS-CWs with Z. aethiopica obtained an average density of approximately $40 \mathrm{~mA} / \mathrm{m}^{2}$. Both systems maintained a slight increase in current density until April $1(04 / 01 / 19)$. After April 1, an exponential increase in current density was observed in the VPS-CWs with Canna hybrids until reaching a maximum peak of approximately $140 \mathrm{~mA} / \mathrm{m}^{2}$. However, the VPS-CWs with Z. aethiopica showed a slight in current density of $61.5 \%$ compared to the start, eventually obtaining a value of almost $65 \mathrm{~mA} / \mathrm{m}^{2}$, much lower compared to the $140 \mathrm{~mA} / \mathrm{m}^{2}$ produced by VPS-CWs with Canna hybrids. It is likely that the Canna hybrids system with higher current density than the variations in external resistance were insufficient or so frequent that it allowed the electronically active microbiota to acclimatize properly with each change of external resistance, promoting a higher current density over time.

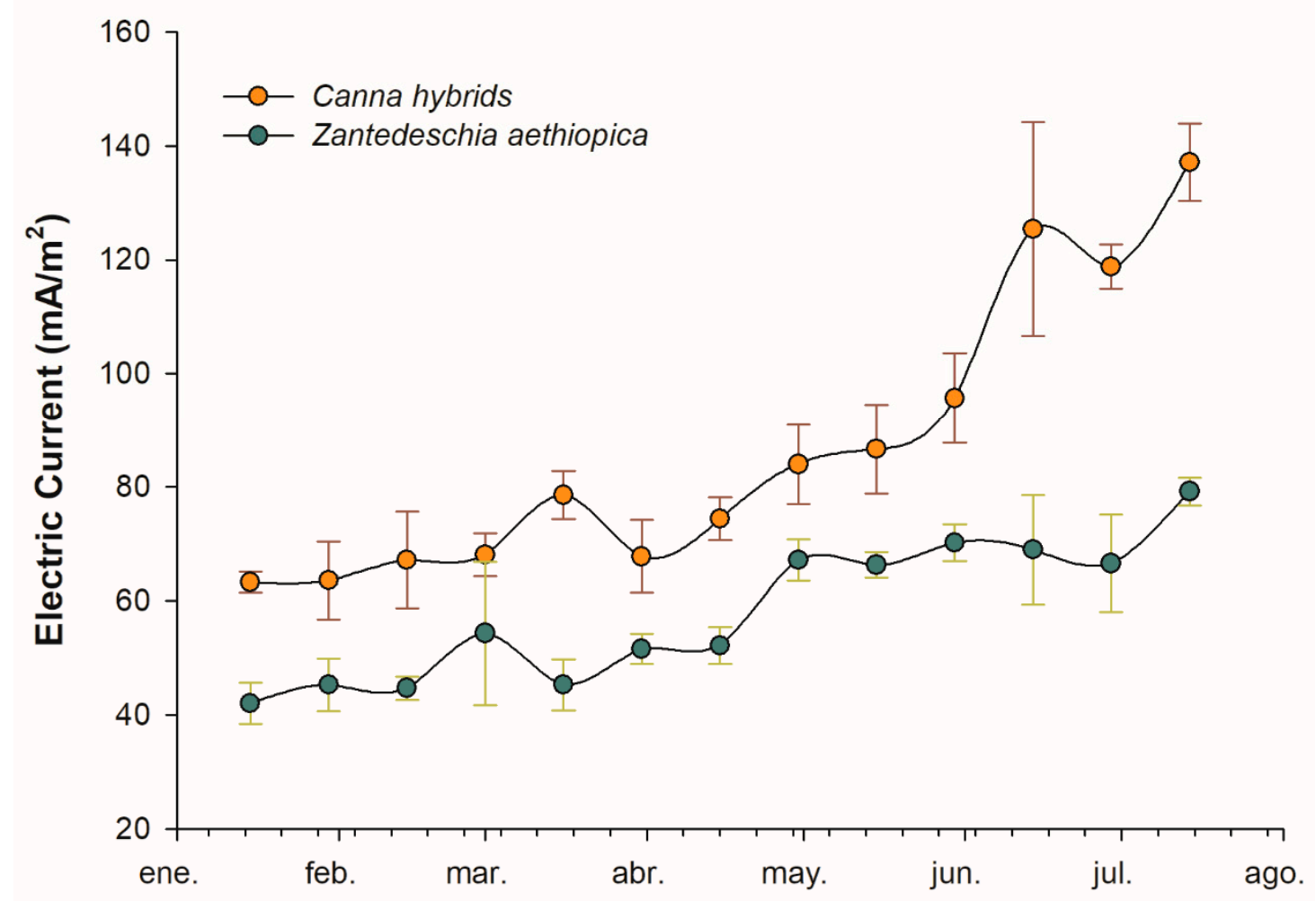

Figure 6. Comparison of the current $\left(\mathrm{mA} / \mathrm{m}^{2}\right)$ generated in the VPS-CW systems using Canna hybrids and Z. aethiopica during 8 months of retention.

Vertical partially saturated constructed wetlands (VPS-CWs) are a commonly used technology for the treatment of domestic and industrial wastewater. It is important to mention that the use of these wetlands with Canna hybrids including activated carbon electrodes and domestic wastewater as substrate presented a better performance than the wetlands with Z. aethiopica under the same conditions. It should also be noted that this method of water treatment and bioelectricity production is an efficient system that generates a good current, voltage, and power density compared to a conventional microbial fuel cell. Studies with microbial combustion cells are generally performed under controlled laboratory conditions [48,52], whereas ours was carried out under environmental conditions in the study area.

Discussion: Bioelectricity Production in VPS-CWs

It is probable that as the residual water degraded (BOD removal), the availability of electrons in the medium increased, and the power also increased exponentially with 
$9.7 \mathrm{~mW} / \mathrm{m}^{2}$ in the system with Canna hybrids and $6.4 \mathrm{~mW} / \mathrm{m}^{2}$ with Z. aethiopica, during the experimentation period for both systems. According to the study carried out by Gadkari, Shemfe, and Sadhukhan, [47], in microbial fuel cells (MFC) treatment systems the high current densities are a function of the initial concentration of organic matter, the chemical oxygen demand (COD). Likewise, some studies [48,49] of conventional microbial fuel cells indicate an increase in the use of the anode for respiration of the electrode by the mixed microbial population at low resistance plus the increase in ionic forces improves conductivity within the system at higher concentrations of organic matter. This could be one of the possible reasons for the increase in power densities. The maximum power measured between the two wetland systems showed a significant difference of $5 \%$, where the power tended to increase as time passed (Figure 4). The system with Canna hybrids produced the highest voltage of $9.7 \mathrm{~mW} / \mathrm{m}^{2}$, and that with Z. aethiopica exhibited the lowest average value of $6.4 \mathrm{~mW} / \mathrm{m}^{2}$. It should be noted that the power values are high compared to a conventional microbial fuel cell. In the study carried out by Capodaglio et al. [50], the maximum power results were $2.1 \mathrm{~mW} / \mathrm{m}^{2}$ using residual water from porcine excreta under laboratory conditions. However, our study with the VPS-CW system showed a maximum power of $9.7 \mathrm{~mW} / \mathrm{m}^{2}$ using domestic wastewater in environmental conditions.

In the study carried out by Capodaglio et al. [50] they analyzed the electrical performance of a microbial fuel cell (MFC). In the obtained results, a removal yield of $52 \%$ of organic matter and a maximum voltage of $31.29(\mathrm{mV})$ were observed. When compared to our study, the best results were observed in the VPS-CW system with the Canna hybrids with a maximum voltage of $750 \mathrm{mV}$ and a residue removal of $98 \%$. This result is likely to have been superior to that of Capodaglio et al. [52] due to the synergy between the microbiota and the plants (Canna hybrids), with an adequate C/N/P (carbon/nitrogen/phosphorus) ratio for microorganisms. This favored the availability of electrons in the medium in a progressive way. Likewise, we assume that the availability of electrons was also due to the growth of Canna hybrids shoots, since as shoots appeared, the wastewater was consumed, the electrons became available, and higher voltage was generated.

With respect to the hypotheses, the study revealed that both species were adapted in the constructed wetland conditions, and the growth of both plats was similar, contradicting hypothesis one. However, the higher removals of NTK and phosphates, voltage, electric current, and electric power in systems with Canna hybrids compared with systems with $Z$. aethiopica support hypothesis two. For BOD, the removal was similar.

The VPS-CWs and the built-in microbial cell could be an efficient technology for marginalized areas, since it is a low-cost system, with efficient wastewater treatment (BDO removal $>90 \%$ ), potential to generate bioelectricity, plus the factor that ornamental plants can also be commercialized.

\section{Conclusions}

Our study demonstrated that VPS-CWs are an efficient technology for the treatment of domestic wastewater, since removal of organic matter was observed. It is important to mention that the use of these wetlands with Canna hybrids, including activated carbon electrodes and domestic wastewater as a substrate, performed better than the wetlands with $Z$. aethiopica under the same conditions. This method of water treatment and bioelectricity production is an efficient system that generates an electric current of $140 \mathrm{~mW} / \mathrm{m}^{2}$, a voltage of $750 \mathrm{mV}$, and a maximum power of $15 \mathrm{~mA} / \mathrm{m}^{2}$, compared to a conventional microbial fuel cell. Unlike microbial combustion cell studies that are generally performed under controlled laboratory conditions, ours was performed under environmental conditions in the study area. This could be an efficient technology for marginalized areas, since it is a low-cost system, with efficient wastewater treatment (BDO removal $>90 \%$ ), potential to generate bioelectricity, plus the advantage that ornamental plants can be commercialized.

Author Contributions: Conceptualization, L.C.S.-H., H.R.G.-M., D.R.-G.; methodology, L.C.S.-H., J.L.M.-M.; validation, L.C.S.-H., O.A.D.Á.-C., N.N.-V., E.S.-D.-C.; formal analysis, L.C.S.-H., O.A.D.Á.C., J.L.M.-M.; investigation, L.C.S.-H., O.Á-C., H.R.G.-M., C.N.; resources, L.C.S.-H., C.N.; data 
curation, L.C.S.-H., D.R.-G.; writing—original draft preparation, L.C.S.-H., H.R.G.-M., D.R.-G.; writing-review and editing, L.C.S.-H., H.R.G.-M., J.L.M.-M.; visualization, L.C.S.-H., H.R.G.-M., O.A.D.Á.-C., E.S.-D.-C.; supervision, L.C.S.-H., O.A.D.Á.-C., C.N., N.N.-V.; project administration, L.C.S.-H., C.N.; funding acquisition, D.R.-G., O.A.D.Á.-C., E.S.-D.-C., C.N., J.L.M.-M., and N.N.-V. All authors have read and agreed to the published version of the manuscript.

Funding: This study was partially funded by the "Tecnológico Nacional de México" with their “Convocatoria de Apoyo a la Investigación Científica y Tecnológica 2018".

Institutional Review Board Statement: Not applicable.

Informed Consent Statement: Not applicable.

Data Availability Statement: The data presented in this study are available on request from the corresponding author.

Acknowledgments: The first author of this study wishes to thank the Tecnológico Nacional de México Campus San Andrés Tuxtla, for allowing him to study his Master of Engineering.

Conflicts of Interest: The authors declare no conflict of interest.

\section{References}

1. Nakase, C.; Zurita, F.; Nani, G.; Reyes, G.; Fernández-Lambert, G.; Cabrera-Hernández, A.; Sandoval, L. Nitrogen Removal from Domestic Wastewater and the Development of Tropical Ornamental Plants in Partially Saturated Mesocosm-Scale Constructed Wetlands. Int. J. Environ. Res. Public Health 2019, 16, 4800. [CrossRef] [PubMed]

2. Doherty, L.; Zhao, Y.; Zhao, X.; Hu, Y.; Hao, X.; Xu, L.; Liu, R. A review of a recently emerged technology: Constructed wetland-microbial fuel cells. Water Res. 2015, 85, 38-45. [CrossRef] [PubMed]

3. Ramírez-Vargas, C.A.; Arias, C.A.; Zhang, L.; Paredes, D.; Brix, H. Community level physiological profiling of microbial electrochemical-based constructed wetlands. Sci. Total Environ. 2020, 137761. [CrossRef] [PubMed]

4. Pelissari, C.; Ávila, C.; Trein, C.M.; García, J.; de Armas, R.D.; Sezerino, P.H. Nitrogen transforming bacteria within a full-scale partially saturated vertical subsurface flow constructed wetland treating urban wastewater. Sci. Total Environ. 2017, 574, 390-399. [CrossRef] [PubMed]

5. Pelissari, C.; Guivernau, M.; Viñas, M.; García, J.; Velasco-Galilea, M.; Souza, S.S.; Ávila, C. Effects of partially saturated conditions on the metabolically active microbiome and on nitrogen removal in vertical subsurface flow constructed wetlands. Water Res. 2018, 141, 185-195. [CrossRef]

6. Gikas, G.D.; Pérez-Villanueva, M.; Tsioras, M.; Alexoudis, C.; Pérez-Rojas, G.; Masís-Mora, M.; Tsihrintzis, V.A. Low-cost approaches for the removal of terbuthylazine from agricultural wastewater: Constructed wetlands and biopurification system. Chem. Eng. J. 2018, 335, 647-656. [CrossRef]

7. Snyder, B.F. The Inclusion of Ecosystem Service Valuations in Bioenergy Cost Analysis: A Case Study of Constructed Wetlands in the Neotropics. Ecol. Econ. 2019, 156, 196-201. [CrossRef]

8. Yang, X.; Chen, Y.; Guo, F.; Liu, X.; Su, X.; He, Q. Metagenomic analysis of the biotoxicity of titanium dioxide nanoparticles to microbial nitrogen transformation in constructed wetlands. J. Hazard. Mater. 2020, 384, 121376. [CrossRef]

9. $\mathrm{Hu}, \mathrm{B} . ; \mathrm{Hu}, \mathrm{S}$; Chen, Z.; Vymazal, J. Employ of arbuscular mycorrhizal fungi for pharmaceuticals ibuprofen and diclofenac removal in mesocosm-scale constructed wetlands. J. Hazard. Mater. 2020, 124524. [CrossRef]

10. Zhang, S.; Liu, F.; Luo, P.; Xiao, R.; Zhu, H.; Wu, J. Nitrous oxide emissions from pilot scale three-stage constructed wetlands with variable nitrogen loading. Bioresour. Technol. 2019, 289, 121687. [CrossRef]

11. Saeed, T.; Majed, N.; Khan, T.; Mallika, H. Two-stage constructed wetland systems for polluted surface water treatment. J. Environ. Manag. 2019, 249, 109379. [CrossRef] [PubMed]

12. Schröder, U. Microbial fuel cells and microbial electrochemistry: Into the next century! ChemSusChem 2012, 5, 959. [CrossRef] [PubMed]

13. Wang, J.; Song, X.; Wang, Y.; Abayneh, B.; Ding, Y.; Yan, D.; Bai, J. Microbial community structure of different electrode materials in constructed wetland incorporating microbial fuel cell. Bioresour. Technol. 2016, 221, 697-702. [CrossRef] [PubMed]

14. Oon, Y.L.; Ong, S.A.; Ho, L.N.; Wong, Y.S.; Dahalan, F.A.; Oon, Y.S.; Nordin, N. Role of macrophyte and effect of supplementary aeration in up-flow constructed wetland-microbial fuel cell for simultaneous wastewater treatment and energy recovery. Bioresour. Technol. 2017, 224, 265-275. [CrossRef] [PubMed]

15. Xu, F.; Cao, F.Q.; Kong, Q.; Zhou, L.L.; Yuan, Q.; Zhu, Y.J.; Wang, Q. Electricity production and evolution of microbial community in the constructed wetland-microbial fuel cell. Chem. Eng. J. 2018, 339, 479-486. [CrossRef]

16. Jadhav, D.A.; Ray, S.G.; Ghangrekar, M.M. Third generation in bio-electrochemical system research-A systematic review on mechanisms for recovery of valuable by-products from wastewater. Renew. Sustain. Energy Rev. 2017, 76, 1022-1031. [CrossRef]

17. Corbella, C.; Puigagut, J. Improving domestic wastewater treatment efficiency with constructed wetland microbial fuel cells: Influence of anode material and external resistance. Sci. Total Environ. 2018, 631, 1406-1414. [CrossRef] 
18. Aguirre-Sierra, A.; Bacchetti-De Gregoris, T.; Salas, J.J.; de Deus, A.; Esteve-Núñez, A. A new concept in constructed wetlands: Assessment of aerobic electroconductive biofilters. Environ. Sci. Water Res. Technol. 2020, 6, 1312-1323. [CrossRef]

19. Gude, V.G. Wastewater treatment in microbial fuel cells-An overview. J. Clean. Prod. 2016, 122, 287-307. [CrossRef]

20. Lombard Latune, R.; Laporte-Daube, O.; Fina, N.; Peyrat, S.; Pelus, L.; Molle, P. Which plants are needed for a French vertical-flow constructed wetland under a tropical climate? Water Sci. Technol. 2017, 75, 1873-1881. [CrossRef]

21. Walter, X.A.; Merino-Jiménez, I.; Greenman, J.; Ieropoulos, I. PEE POWER ${ }^{\circledR}$ urinal II-Urinal scale-up with microbial fuel cell scale-down for improved lighting. J. Power Sources 2018, 392, 150-158. [CrossRef] [PubMed]

22. Xu, L.; Zhao, Y.; Fan, C.; Fan, Z.; Zhao, F. First study to explore the feasibility of applying microbial fuel cells into constructed wetlands for COD monitoring. Bioresour. Technol. 2017, 243, 846-854. [CrossRef] [PubMed]

23. Do, M.H.; Ngo, H.H.; Guo, W.S.; Liu, Y.; Chang, S.W.; Nguyen, D.D.; Ni, B.J. Challenges in the application of microbial fuel cells to wastewater treatment and energy production: A mini review. Sci. Total Environ. 2018, 639, 910-920. [CrossRef] [PubMed]

24. Montiel, V.; Valero, D.; Gallud, F.; García-García, V.; Expósito, E.; Iniesta, J. Prospective Applications of Renewable Energy-Based Electrochemical Systems in Wastewater Treatment. In Electrochemical Water and Wastewater Treatment; Butterworth-Heinemann: Oxford, UK, 2018; pp. 513-541. [CrossRef]

25. Hagen, M.; Dörfler, S.; Fanz, P.; Berger, T.; Speck, R.; Tübke, J.; Kaskel, S. Development and costs calculation of lithium-sulfur cells with high sulfur load and binder free electrodes. J. Power Sources 2013, 224, 260-268. [CrossRef]

26. Lawry, S.; Samii, C.; Hall, R.; Leopold, A.; Hornby, D.; Mtero, F. The impact of land property rights interventions on investment and agricultural productivity in developing countries: A systematic review. J. Dev. Eff. 2017, 9, 61-81. [CrossRef]

27. Mateo, N.; Nani, G.; Montiel, W.; Nakase, C.; Salazar-Salazar, C.; Sandoval, L. Effect of Canna Hibryds in Wetlands Built Specifically Saturated for the Treatment of Pig Waters. Rinderesu 2020, 4, 59-68. Available online: http://rinderesu.com/index. $\mathrm{php} / \mathrm{rinderesu} / \mathrm{article} / \mathrm{view} / 41$ (accessed on 1 October 2020).

28. Di, L.; Li, Y.; Nie, L.; Wang, S.; Kong, F. Influence of plant radial oxygen loss in constructed wetland combined with microbial fuel cell on nitrobenzene removal from aqueous solution. J. Hazard. Mater. 2020, 122542. [CrossRef]

29. Caicedo Díaz, G.E.; Rozo Wilches, L.S.; Rengifo, G. La achira: Alternativa Agroindustrial Para Áreas de Economía Campesina. Produmedios 2003, 30. Available online: http://bibliotecadigital.agronet.gov.co/bitstream/11348/4071/1/La\%20achira\%20 tecnicas\%20de\%20cultivo\%20y\%20beneficio.pdf. (accessed on 9 October 2020).

30. Casierra-Posada, F.; Nieto, P.J.; Ulrichs, C. Growth, Production and Flower Quality in Calla Lily (Zantedeschia aethiopica (L.) K. Spreng) exposed to different light quality. Rev. UDCA Actual. Divulg. Científica 2012, 15, 97-105. Available online: http: //www.scielo.org.co/scielo.php?script=sci_arttext\&pid=S0123-42262012000100011 (accessed on 15 October 2020).

31. Sánchez-Olivares, E.; Marín-Muñiz, J.L.; Hernandez-Alarcón, M.E. Radial oxygen loss by roots of native tropical wetland plants of Veracruz in response of different flooding conditions. Bot. Sci. 2019, 97, 202-210. [CrossRef]

32. Sandoval, L.; Zurita, F.; Ángel-Coronel, D.; Andrés, O.; Adame-García, J.; Marín-Muñíz, J.L. Influence of a new ornamental species (Spathiphyllum blandum) on the removal of cod, nitrogen, phosphorus and fecal coliforms: A mesocosm wetland study with pet and tezontle substrates. Water Sci. Technol. 2020. [CrossRef] [PubMed]

33. Sandoval-Herazo, L.C.; Marín-Muñiz, J.L.; Orduñas, M.G.H.; Aleman-Chang, A.J. Role of Wetland Plants and Use of Ornamental Flowering Plants in Constructed Wetlands for Wastewater Treatment: A Review. Appl. Sci. 2019, 9, 685. [CrossRef]

34. Vasconez, R.D.A.; Utreras, V.P.C.; Suquillo, I.D.V. Efecto Del Carbón Activado En La Germinación Y Brotación In Vitro De Citrus Limon (L.) Y Su Dinámica De Crecimiento. Bionatura 2018, 3. [CrossRef]

35. Sandoval, L.; Marín-Muñiz, J.L.; Zamora-Castro, S.A.; Sandoval-Salas, F.; Alvarado-Lassman, A. Evaluation of Wastewater Treatment by Microcosms of Vertical Subsurface Wetlands in Partially Saturated Conditions Planted with Ornamental Plants and Filled with Mineral and Plastic Substrates. Int. J. Environ. Res. Public Health 2019, 16, 167. [CrossRef]

36. Decezaro, S.T.; Wolff, D.B.; Pelissari, C.; Ramírez, R.J.; Formentini, T.A.; Goerck, J.; Sezerino, P.H. Influence of hydraulic loading rate and recirculation on oxygen transfer in a vertical flow constructed wetland. Sci. Total Environ. 2019, 668, 988-995. [CrossRef]

37. Xiao, N.; Wu, R.; Huang, J.J.; Selvaganapathy, P.R. Development of a xurographically fabricated miniaturized low-cost, highperformance microbial fuel cell and its application for sensing biological oxygen demand. Sens. Actuators B Chem. 2020, 304, 127432. [CrossRef]

38. Kumar, S.; Pratap, B.; Dubey, D.; Dutta, V. Microbial Communities in Constructed Wetland Microcosms and Their Role in Treatment of Domestic Wastewater. In Emerging Eco-friendly Green Technologies for Wastewater Treatment; Springer: Singapore, 2020; pp. 311-327. [CrossRef]

39. Hussain, Z.; Arslan, M.; Malik, M.H.; Mohsin, M.; Iqbal, S.; Afzal, M. Treatment of the textile industry effluent in a pilot-scale vertical flow constructed wetland system augmented with bacterial endophytes. Sci. Total Environ. 2018, 645, 966-973. [CrossRef]

40. Tulun, Ş. Treatment of Leachate Using Up-Flow Anaerobic Sludge Blanket Reactors/Vertical Flow Subsurface Constructed Wetlands. Ecol. Chem. Eng. S 2020, 27, 129-137. [CrossRef]

41. Ashraf, S.; Afzal, M.; Rehman, K.; Tahseen, R.; Naveed, M.; Zahir, Z.A. Enhanced remediation of tannery effluent in constructed wetlands augmented with endophytic bacteria. Desalination Water Treat. 2018, 102, 93-100. [CrossRef]

42. Lin, C.J.; Chyan, J.M.; Zhuang, W.X.; Vega, F.A.; Mendoza, R.M.O.; Senoro, D.B.; Liao, C.H. Application of an innovative front aeration and internal recirculation strategy to improve the removal of pollutants in subsurface flow constructed wetlands. J. Environ. Manag. 2020, 256, 109873. [CrossRef] 
43. Rodríguez-Momroy, J.; Durán-de-Bazúa, C. Remoción de Nitrógeno en un Sistema de Tratamiento de Aguas Residuales Usando Humedales Artificiales de Flujo Vertical a Escala de Banco. Tecnol. Cienc. Educ. 2006, 21, 25-33. Available online: https: / / www.redalyc.org/articulo.oa?id=48221104 (accessed on 25 October 2020).

44. Rahimikhoob, H.; Sohrabi, T.; Delshad, M. Development of a Critical Nitrogen Dilution Curve for Basil (Ocimum basilicum L.) Under Greenhouse Conditions. J. Soil Sci. Plant Nutr. 2020, 1-11. [CrossRef]

45. Marín-Muñiz, J.L.; García-González, M.C.; Ruelas-Monjardín, L.C.; Moreno-Casasola, P. Influence of different porous media and ornamental vegetation on wastewater pollutant removal in vertical subsurface flow wetland microcosms. Environ. Eng. Sci. 2018, 35, 88-94. [CrossRef]

46. Casierra-Martínez, H.A.; Charris-Olmos, J.C.; Caselles-Osorio, A.; Parody-Muñoz, A.E. Organic matter and nutrients removal in tropical constructed wetlands using Cyperus ligularis (Cyperaceae) and Echinocloa colona (Poaceae). Water Air Soil Pollut. 2017, 228, 338. [CrossRef]

47. Gadkari, S.; Shemfe, M.; Sadhukhan, J. Microbial fuel cells: A fast converging dynamic model for assessing system performance based on bioanode kinetics. Int. J. Hydrog. Energy 2019, 44, 15377-15386. [CrossRef]

48. Feng, Y.; Wang, X.; Logan, B.E.; Lee, H. Brewery wastewater treatment using air-cathode microbial fuel cells. Appl. Microbiol. Biotechnol 2008, 78, 873-880. [CrossRef] [PubMed]

49. Yu, Y.Y.; Song, H.; Yan, X.; Chen, W.N. The effect of external resistance on biofilm formation and inte rnal resistance in Shewanella inoculated microbial fuel cells. RSC Adv. 2016, 6, 20317-20323. [CrossRef]

50. Capodaglio, A.G.; Molognoni, D.; Puig, S.; Balaguer, M.D.; Colprim, J. Role of Operating Conditions on Energetic Pathways in a Microbial Fuel Cell. Energy Procedia 2015, 74, 728-735. [CrossRef]

51. Mohan, S.V.; Raghavulu, S.V.; Peri, D.; Sarma, P.N. Integrated function of microbial fuel cell (MFC) as bio-electrochemical treatment system associated with bioelectricity generation under higher substrate load. Biosens. Bioelectron. 2009, 24, $2021-2027$. [CrossRef]

52. Walter, X.A.; Santoro, C.; Greenman, J.; Ieropoulos, I. Self-stratifying microbial fuel cell: The importance of the cathode electrode immersion height. Int. J. Hydrog. Energy 2019, 44, 4524-4532. [CrossRef] 